\title{
ARTIKEL
}

\section{Multi-jobbing als employability-strategie}

Luc Dorenbosch, Oleg Boneschansker, Bruno Fermin, Saskia Andriessen, Jos Sanders \& Goedele Geuskens ${ }^{*}$

Werkenden voor wie de werksituatie bestaat uit een combinatie van twee of meer banen, vormen geen uitzondering op de Nederlandse arbeidsmarkt. Toch weten we nog weinig over de motieven voor het combineren van meerdere banen - ofwel multi-jobbing. Dit artikel betreft een kwalitatieve verkenning onder twintig multi-jobbers van 45 jaar en ouder die recentelijk een transitie hebben gemaakt van één baan in loondienst naar meerdere banen in loondienst of een baan gecombineerd met zzp-schap. Multi-jobbing als alternatieve (tussen)vorm van arbeidsmobiliteit is nog een erg onderbelicht onderzoeksthema en relevant voor werkenden in een latere loopbaanfase waarvoor reguliere baanmobiliteit veel minder vanzelfsprekend is. We beschrijven de diverse push-en pullmotieven voor het aangaan van een combinatiebaan of hybride baan die duiden op multi-jobbing als noodsituatie, ideaalsituatie of overgangssituatie. De studie maakt verder duidelijk dat een groot deel van de gë̈nterviewden een tweede baan bewust gebruikt als persoonlijke employability-strategie. We bediscussiëren multi-jobbing als arbeidsmarktgedrag dat in een latere loopbaanfase inspeelt op de onzekerheid die gepaard gaat met mobiliteit.

\section{Introductie}

Recente arbeidsmarktstatistieken tonen de groei van het aandeel werkenden met twee of meer banen. Zowel trendcijfers van SCP (2015) als CBS (2014) tonen een stijging van het aandeel werkenden op de Nederlandse arbeidsmarkt dat naast één baan in loondienst ook een andere baan in loondienst heeft (combinatievariant) of ernaast ook als zelfstandige werkt (hybride variant). CBS komt uit op 7,6\% in 2013 (ten opzichte van 5,5\% in 2003). Het SCP-aanbodspanel komt uit op 8\% in 2012 (ten opzichte van 3\% in 1986). Ook cijfers van de Nationale Enquête Arbeidsomstandigheden (NEA) komen uit op een percentage van 8,5\% in 2012 van de werkenden die er meerdere banen op nahouden (Dorenbosch et al., 2013). Gemiddeld gaat het dus over een half miljoen zogeheten 'multi-jobbers' (Neefs \& Herremans, 2011) op de Nederlandse arbeidsmarkt. Naast de grotendeels overeenkomstige percentages uit drie verschillende steekproeven is er ook consensus over de trend dat vooral de combinatie van werken in loondienst én werken als zelfstandige het meest bijdraagt aan de algehele stijging in het aandeel multi-jobbers.

* Luc Dorenbosch, Jos Sanders en Goedele Geuskens zijn werkzaam bij TNO. E-mail: luc.dorenbosch@tno.nl. Oleg Boneschansker, Bruno Fermin en Saskia Andriessen waren ten tijde van het onderzoek werkzaam bij TNO. 
Weinig is echter bekend over de redenen van deze ontwikkeling op de arbeidsmarkt. Traditioneel economisch onderzoek volgt de redenering van de hoursconstraint'-hypothese, die stelt dat naarmate de verdiencapaciteit in de hoofdbaan lager ligt dan wenselijk, de kans groter wordt dat een werkende er meerdere banen op nahoudt (Shishko \& Rostker, 1976; Renna \& Oaxaca, 2006; Wu et al., 2009). De 'werkende armen'-verklaring, waarbij steeds meer mensen moeite hebben om ondanks het hebben van fulltime werk financieel te kunnen rondkomen, ligt daarmee voor de hand. De term 'stapelbanen', die hierbij steeds meer gebezigd wordt, verwijst naar het fenomeen dat werkenden uren bij meerdere werkgevers moeten gaan stapelen om een redelijk inkomen te verdienen.

Toch is multi-jobbing geen verschijnsel dat louter aan de onderkant van de arbeidsmarkt plaatsvindt. Alle drie bovengenoemde steekproeven wijzen er al op dat het bijvoorbeeld meer voorkomt onder hoger opgeleiden dan onder het lager opgeleide deel van de werkenden. Ook blijkt het beeld van multi-jobbers die ongezond lange werkweken draaien in Nederland niet te stroken met de beschikbare cijfers. Het gemiddeld aantal werkuren van een persoon met twee banen in loondienst ligt in het CBS-onderzoek (2014) opgeteld lager (31,8 uur) dan het gemiddelde aantal werkuren van personen met één baan (34,1 uur). In de hybride variant maken multi-jobbers gemiddeld 39 uur per week.

De beschikbare cijfers voor Nederland tellen dus niet op tot het (angst)beeld van spreekwoordelijke 'Amerikaanse toestanden' waarbij laaggeschoolde werknemers met meerdere banen dagelijks moeten rennen van baan naar baan en hierbij zeer lange werkdagen draaien om uiteindelijk amper te kunnen rondkomen. De redenen voor het combineren van banen zijn waarschijnlijk veel diverser. Dit wordt bevestigd door TNO-onderzoek van Dorenbosch et al. (2013), waarin multi-jobbers direct gevraagd werd naar de hoofdreden voor het hebben van meerdere banen. Hieruit bleek dat een vijfde van de multi-jobbers in Nederland financiële noodzaak als hoofdmotief noemde. Andere evenzeer belangrijke hoofdmotieven zijn bijvoorbeeld iets extra's verdienen, afwisseling in werk, persoonlijke ontwikkeling of behoud van werkzekerheid.

\section{Multi-jobbing in een latere loopbaanfase}

In deze bijdrage richten we ons specifiek op de werknemers die in een latere loopbaanfase een transitie maken van één baan naar meerdere banen. Het ontbreekt in wetenschappelijk onderzoek aan kennis over de redenen van 'multi-jobbing' als transitioneel arbeidsmarktgedrag. Daarbij staat deze oudere doelgroep met een vergrijzende arbeidspopulatie nadrukkelijk in de schijnwerpers. Enerzijds vanwege de noodzaak om langer door te werken en anderzijds vanwege een sterk geringere vrijwillige arbeidsmobiliteit in vergelijking met jongere werknemers (Deelen et al., 2014). Daarbij werken oudere werknemers vaker in de krimpsegmenten van de arbeidsmarkt (Bosch \& Ter Weel, 2013).

Werkgevers staan hiermee voor een groeiende groep werknemers die tegen hun functieplafond aan (gaan) lopen en voor wie alternatieve (of tweede) loopbanen belangrijker worden om door- en uitstroom te bewerkstelligen. Toch zijn de personeelsinstrumenten hiertoe in praktijk beperkt en duur en zijn traditionele vervroegde uitstroomroutes de laatste jaren afgebouwd (OECD, 2014). In discussies 
over demotie (begin 2015 weer door minister Blok aangekaart om op te nemen in een nieuwe ambtenaren-cao) toont zich het doorstroomdilemma met betrekking tot ouder wordende werknemers. Multi-jobbing kan voor oudere werknemers met een vast contract een aantrekkelijke manier zijn om toch in beweging te komen op de arbeidsmarkt wanneer men hierdoor de verworven zekerheden van de vaste aanstelling in de hoofdbaan niet hoeft op te geven. Het bestuderen van alternatief arbeidsmarktgedrag waarbij werknemers in een latere loopbaanfase meerdere banen gaan combineren, is relevant voor het begrijpen van deze arbeidsmarktdynamiek die de afgelopen jaren meer is gaan voorkomen. Zeker voor de groep 45plussers op de arbeidsmarkt, voor wie vrijwillige arbeidsmobiliteit geen vanzelfsprekendheid is. We kiezen voor een kwalitatief onderzoek naar de specifieke vraag waarom werknemers in een latere loopbaanfase een transitie maken van een baan in loondienst naar meerdere banen in loondienst of naar een hybride variant met een deel zelfstandig ondernemerschap.

\section{Eerder onderzoek: diverse multi-job-motieven}

Uit internationale literatuur blijkt dat werkenden diverse redenen kunnen hebben voor multi-jobbing (zie Wu et al., 2009; Hipple, 2010; Dickey et al., 20011). Er zijn grofweg een vijftal redenen in te onderscheiden. Naast (1) het eerdergenoemde 'hours constraint'-motief is een ander financieel motief dat werknemers (2) gewoon iets extra's willen verdienen boven op een inkomen dat reeds toereikend is, bijvoorbeeld om te sparen voor verwachte hogere uitgaven in de toekomst (zoals kinderen die gaan studeren, geplande wereldreis). Boven op deze twee meer financieel gedreven motieven onderscheiden $\mathrm{Wu}$ et al. (2009) twee niet-financiële hoofdredenen: (3) kennis en ervaring opdoen in heterogene banen/beroepen voor meer afwisseling of plezier in het werk, of (4) om vooruitlopend op een dreigende beëindiging van een dienstverband alvast baanzekerheid in een ander dienstverband te verkrijgen ('hedging'). Verder wordt in sommige studies (Hipple, 2010; Panos et al., 2014) ook verwezen naar (5) het ondernemers-motief, waarbij een tweede baan zelfstandige activiteiten omvat als opmaat voor het starten van een eigen bedrijf. De schaarse publicaties (Dorenbosch et al., 2013) waarin aan multi-jobbers zelf wordt gevraagd wat hun motieven zijn voor meerdere banen, concludeerden dat elk van deze financiële en niet-financiële redenen een rol kan spelen, zodat de redenen elkaar in praktijk niet uitsluiten.

Het bovenstaande onderscheid in multi-job-motieven is vergelijkbaar met het onderzoek naar motieven voor het starten van een eigen onderneming. Hierin wordt onderscheid gemaakt tussen de noodzaak- en kansgedreven ondernemers (Reynolds et al., 2001). Waar door noodzaak gedreven ondernemerschap vooral push-motieven kent ('er zijn geen andere mogelijkheden voor werk dan zelfstandig ondernemer worden'), kent kansgedreven ondernemerschap voornamelijk pull-motieven ('in het ondernemerschap nieuwe zakelijke kansen zien en pakken'). Eenzelfde verdeling verwachten we ook te kunnen aanbrengen in het motief om een transitie te maken van één naar meerdere banen. Push- en pullmotieven kunnen daarbij financieel zijn (bijvoorbeeld niet kunnen rondkomen van één baan versus extra kunnen verdienen met een tweede baan) of niet-financieel 
zijn (bijvoorbeeld te weinig uitdaging in één baan versus nieuwe ontwikkelkansen in een tweede baan benutten).

\section{Multi-jobbing als employability-strategie}

In deze bijdrage gaan we specifiek in op de motieven om in een latere loopbaanfase van een baan in loondienst de stap te maken naar meerdere banen. We verwachten daarbij dat het behoud van opgebouwde baan-, werk- of inkomenszekerheid een grotere rol speelt dan voor jongere werknemers. Zoals eerder vermeld is het in een latere loopbaanfase niet gemakkelijk en aantrekkelijk om een geheel nieuwe stap te maken naar een andere werkgever of naar een meer onzeker bestaan als ondernemer. Hoewel het grootste deel van de Nederlandse zzp'ers 45 jaar of ouder is, vonden Kösters et al. (2013) dat de zzp-instroom amper op het conto komt van transities uit één baan in loondienst. De kans dat oudere werknemers van een baan bij een werkgever naar een bestaan als zzp'er gaan, wordt significant kleiner met het toenemen van de leeftijd. Oudere werkenden worden vooral zzp'er vanuit een situatie van inactiviteit of werkloosheid. Het gaan van één baan naar meerdere banen is in het palet van mogelijke arbeidsmarkttransities een tussenvorm. Het gaat dan om niet-volledige transities, omdat men kiest voor het behoud van zekerheden uit de hoofdbaan of het spreiden van zekerheidsrisico's over meerdere banen. Zodoende bekijken we in dit onderzoek ook de wijze waarop multi-jobbing een persoonlijke employability-strategie van werknemers is.

Employability gaat over het vermogen van werknemers om betaald werk te vinden en duurzaam inzetbaar te blijven op de arbeidsmarkt. Specifieker verwijst employability naar de mate waarin werknemers in staat zijn zichzelf langdurig baan-, werk- en/of inkomenszekerheid te verschaffen (Wilthagen \& Tros, 2004). Een recente studie van Panos et al. (2014) toont dat voor de verdere kansen op de arbeidsmarkt, multi-jobbing de kansen op een nieuwe baan of het starten van een eigen bedrijf vergroot en tegelijkertijd de kans op werkloosheid of inactiviteit significant verkleint. Dit geldt vooral wanneer de multi-jobber er twee andersoortige banen op nahoudt. Hierdoor veronderstellen de auteurs dat dit, in vergelijking met twee gelijksoortige banen, het menselijk kapitaal van multi-jobbers verruimt en de kansen op succesvolle mobiliteit op de arbeidsmarkt vergroot. Verder toont een recente studie van Raffiee en Feng (2014) dat Amerikaanse werknemers die zelfstandig gaan ondernemen meer langdurig succesvolle ondernemingen stichten wanneer ze als start-up nog deels voor hun werkgever blijven werken. Deze 'hybride route' naar ondernemerschap heeft het voordeel dat men langer de financieel onzekere startfase kan volhouden totdat de onderneming geheel zelfstandig kan draaien. Pas als de motor warm is gelopen, maakt men de transitie naar volledig ondernemerschap.

In navolging van deze onderzoeken bekijken we de motieven om een transitie naar meerdere banen te maken ook in relatie tot een persoonlijke employabilitystrategie die mogelijk past bij werkenden in een latere loopbaanfase. 


\section{Deze studie}

Het doel van deze studie was om een beter kwalitatief beeld te krijgen van wat het maken van een transitie van één baan naar meerdere banen inhoudt voor werkenden in een latere loopbaanfase. Dit is relevant in de context van een vergrijzende arbeidsmarkt waarin de employability van oudere werknemers die ook langer moeten doorwerken steeds verder onder druk staat. Voor deze studie interviewden we twintig multi-jobbers in een latere loopbaanfase (45 jaar of ouder): tien multi-jobbers die recentelijk (in de afgelopen twee jaar) vanuit één baan in loondienst naar meerdere banen in loondienst zijn gegaan (= transitie naar een combinatiebaan) en tien multi-jobbers die vanuit één baan in loondienst naar een betrekking in loondienst en als zzp'er zijn gegaan (= transitie naar een hybride baan). De hoofvragen van dit onderzoek luiden:

- Welke varianten van het combineren van banen komen er in de praktijk voor?

- Wat zijn specifieke push- en pullfactoren voor het combineren van banen?

- Hoe draagt multi-jobbing bij aan de employability in latere loopbaanfases?

\section{Methode}

\section{Onderzoeksopzet}

Deze kwalitatieve studie is uitgevoerd door middel van semi-gestructureerde telefonische interviews. De studie is onderdeel van STREAM, een prospectieve cohortstudie van inmiddels vier jaarlijkse metingen onder 45-64 jarigen (werkenden, zelfstandigen en werklozen) gericht op het onderzoeken van de determinanten van langer gezond en productief doorwerken (Ybema et al., 2014). Deelnemers aan deze cohortstudie kunnen als onderdeel van de vragenlijst vrijwillig aangeven of ze benaderd kunnen worden voor vervolgonderzoek, waarbij ze hun naam en telefoonnummer achterlaten.

\section{Inclusie van deelnemers}

De STREAM-studie biedt de unieke mogelijkheid om een gerichte keuze te maken in de te benaderen deelnemers aan deze kwalitatieve studie naar het combineren van banen. Hierbij zijn de volgende inclusiecriteria gehanteerd: (1) potentiële deelnemers hebben op het moment van het interview een combinatiebaan of een hybride baan, (2) ze hebben minimaal twee jaar hieraan voorafgaand gewerkt in een enkele betaalde baan in loondienst (hebben dus recentelijk een transitie gemaakt), (3) ze verkrijgen uit beide banen een inkomen (geen vrijwilligerswerk met evt. onkostenvergoeding). Deze inclusiecriteria maken dat de deelnemers aan dit onderzoek allemaal kunnen antwoorden vanuit hun huidige situatie in een combinatiebaan of hybride baan. Daarnaast hebben ze allemaal recentelijk een transitie gemaakt vanuit een vergelijkbare situatie (één baan in loondienst). Dit bevordert de vergelijkbaarheid van de deelnemers. Bovendien kan het helpen om de respondenten scherper te laten antwoorden op de verschillen tussen één baan en meerdere banen. 
Op deze criteria konden met behulp van de longitudinale vragenlijstdata potentiele deelnemers worden onderscheiden. Werkenden in verschillende soorten baansamenstellingen zijn gefilterd op basis van antwoordcombinaties op de volgende vraag: 'In welke situatie zit u momenteel?' ( 1 = Eén betaalde baan als werknemer (in loondienst, ook uitzendkracht of oproepkracht); 2 = Meerdere betaalde banen als werknemer; 3 = Werkzaam als zelfstandige of ondernemer). Op deze vraag konden respondenten meerdere antwoorden geven.

De T3-meting van de STREAM-studie uit november 2012 bevat 307 respondenten die enkel aangaven twee of meerdere betaalde banen $(=2)$ te hebben. Zij hebben een combinatiebaan. Werkenden met een hybride baan zijn gecodeerd door werkzaam te zijn als zelfstandige $(=3)$ samen met het hebben van een betaalde baan als werknemer $(=1)$ of samen met het hebben van meerdere betaalde banen als werknemer $(=2)$. Op basis van deze antwoordcombinatie zijn er op T3 238 werkenden met een hybride baan. Deze respondenten hebben ook deelgenomen aan de T2-meting (peildatum: november 2011). Door de baansituatie op T2 en T3 met elkaar te vergelijken werd duidelijk dat 90 van de 307 respondenten een recente transitie hadden gemaakt van één betaalde baan naar een combinatiebaan, tegenover 48 van de 238 respondenten die een recente transitie hebben gemaakt van één betaalde baan naar een hybride baan. Op basis van de gegeven toestemming voor vervolgonderzoek was het mogelijk om uit deze groepen 42 mensen met een recente transitie naar een combinatiebaan en 21 mensen met een recente transitie naar een hybride baan telefonisch te benaderen.

\section{Selectie van deelnemers}

In de maanden april en mei van 2013 zijn de potentiële deelnemers telefonisch benaderd. Bij het benaderen is gestratificeerd naar: type baansamenstelling (combinatiebaan versus hybride baan), omvang dienstverband in de hoofdbaan (32 uur of meer versus minder dan 32 uur), opleiding (laag/middelbaar versus hoog) en geslacht. In totaal werd hiermee beoogd twintig deelnemers te kunnen selecteren met een maximaal contrast in het type banen/beroepen dat werd gecombineerd, de redenen voor een transitie en de gevolgen voor de werkende. Uit kwantitatieve studies (Huiskamp et al., 2011; Dorenbosch et al., 2015) naar werknemerverschillen in de prevalentie en de redenen voor het combineren van banen is bekend dat deze werknemerkenmerken ertoe doen. Dit sluit aan bij het kwalitatieve doel om een zo compleet mogelijk beeld te krijgen van de verschillende redenen en gevolgen van een transitie naar meerdere banen. Maximaal contrast heeft als doel een vroegtijdige verzadiging in de diversiteit aan antwoorden van deelnemers tegen te gaan. Deze situatie kan zich eerder voordoen bij een te eenzijdige groep deelnemers. Met de inclusiecriteria hebben we dus getracht een goede focus aan te brengen (een bepaalde transitiegroep), terwijl we in de selectie juist zoveel mogelijk heterogeniteit in deze specifieke transitiegroep nastreven. Omdat we deze kenmerken van de transitiegroep kenden uit de STREAM-data werd hierop strategisch geanticipeerd in het uitnodigen van de deelnemers tot deelname. Hierdoor hoefde in principe niet iedereen gebeld te worden, maar werden deelnemers gericht gebeld totdat er een acceptabele selectie was. 
Het telefonisch benaderen leverde uiteindelijk de beoogde twintig deelnemers met een meer dan acceptabel contrast in demografische kenmerken. Na een check op de inclusiecriteria stemden ze in met een telefonisch interview dat op een ander tijdstip zou plaatsvinden. Beoogd werd dat van de twintig deelnemers er tien een combinatiebaan en tien een hybride baan moesten hebben, wat ook gehaald is. Van de tien met een combinatiebaan werken er zes parttime (drie laag/ middelbaar opgeleid en drie hoogopgeleid) en vier fulltime (drie laag/middelbaar opgeleid en één hoogopgeleid) in de hoofdbaan. De verdeling man/vrouw is $50 / 50 \%$. Van de tien met een hybride baan werken er in de hoofdbaan vijf parttime (drie laag/middelbaar opgeleid en twee hoogopgeleid) en vijf fulltime (drie laag/middelbaar opgeleid en twee hoogopgeleid). De verdeling man/vrouw is $60 / 40 \%$. Zie tabel 1 voor de specifieke kenmerken van de in deze studie geïncludeerde deelnemers.

\section{Interviewprocedure}

De interviews zijn verricht door twee onderzoekers met ruime ervaring op dit gebied. De interviewopzet is geprotocolleerd en gericht op een interview van 30 minuten. Het protocol is voorafgaand aan de interviews kritisch becommentarieerd door een expert op het gebied van kwalitatieve onderzoekdesigns en -methodes. Daarnaast zijn er in de weken voor de start van de studie twee pilot interviews afgenomen met personen met een combinatiebaan en met een hybride baan, waarbij beide interviewers betrokken waren. Op basis hiervan zijn enkele aanpassingen gedaan aan het interviewprotocol. De interviews zijn overdag en 's avonds afgenomen op een door de deelnemers gewenste datum en tijd. Voorafgaand aan het interview is toestemming gevraagd om het interview (digitaal) op te nemen om dit op een later moment uit te werken.

Het interview bestond uit vier onderdelen. Het eerste deel omvatte vragen over de exacte kenmerken van de huidige situatie van een combinatiebaan of hybride baan en de wijze waarop de transitie vanuit een betaalde baan is verlopen. Het tweede deel ging in op de redenen om te gaan multi-jobben, waarbij werd doorgevraagd naar de mate waarin de transitie is te typeren als vrijwillig of gedwongen. Het derde deel ging over de manier waarop de deelnemer de huidige baansituatie ervoer ten opzichte van de één-baans-situatie, en wat positieve en/of negatieve gevolgen waren van specifiek het hebben van meerdere banen. Het laatste deel betrof de vraag in hoeverre en waarom de huidige situatie er ( $g$ )een was die ze zouden willen doorzetten tot op latere leeftijd, aangevuld met de vraag om de ideale baansituatie voor de toekomst te schetsen. 


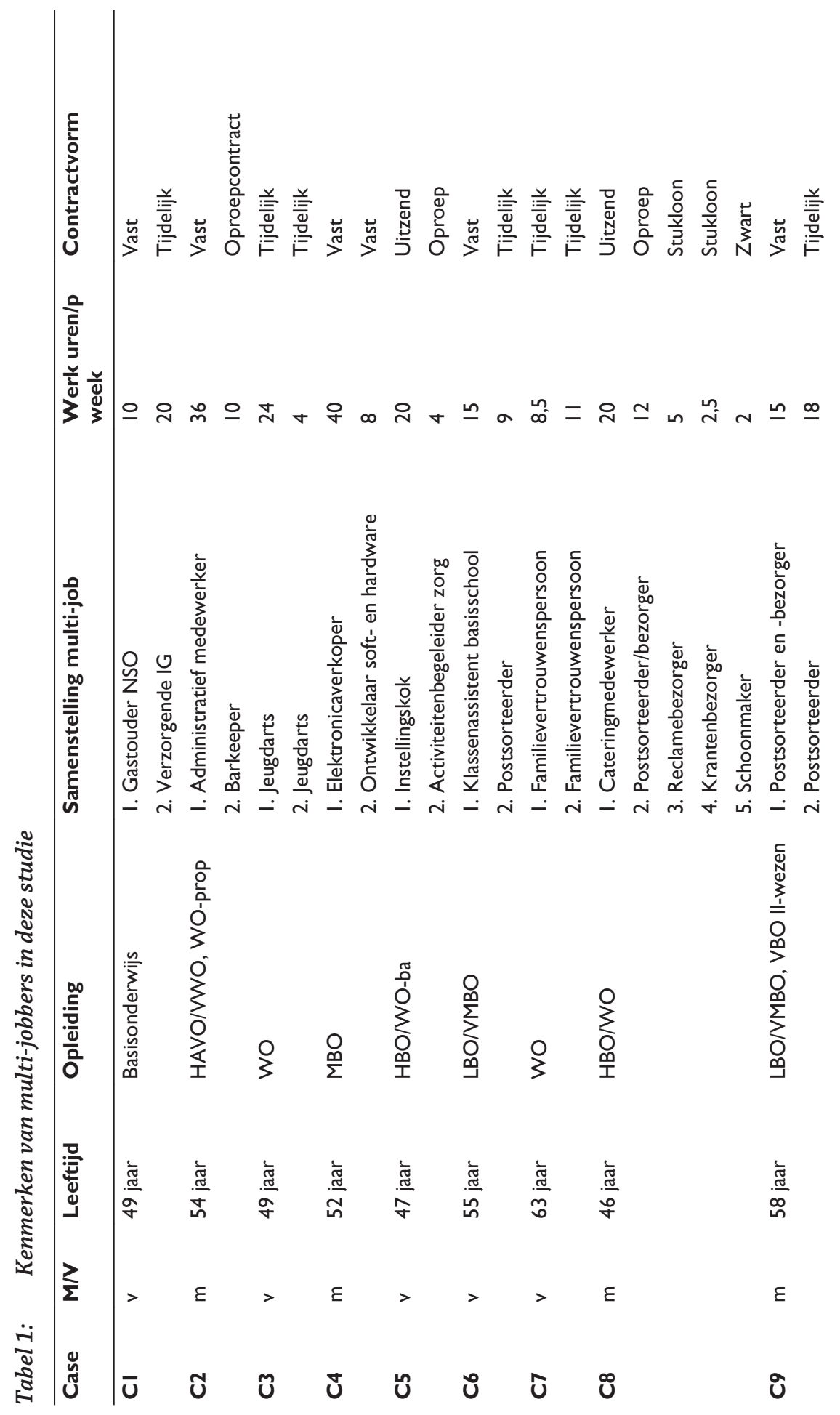




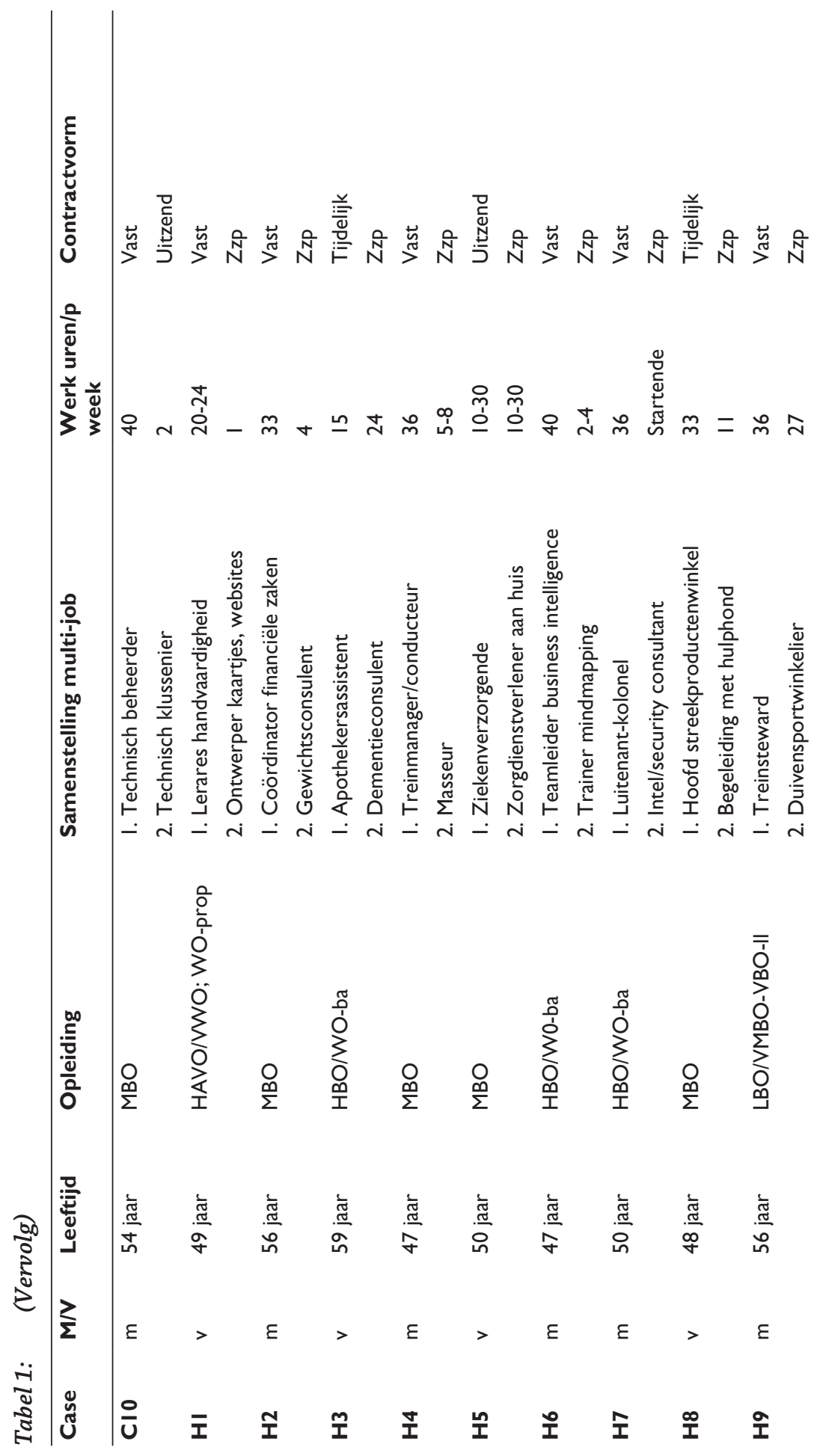




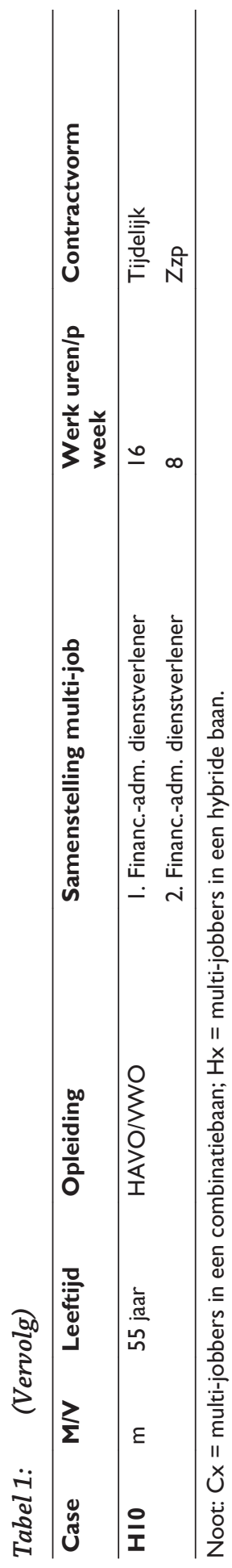




\section{Resultaten}

\section{Baankenmerken van multi-jobbers}

Tabel 1 toont allereerst een grote verscheidenheid in de banen die gecombineerd worden in loondienst (gecodeerd als CX) of in combinatie met een zelfstandige betrekking (gecodeerd als HX). De meerderheid van de combinatiebanen of hybride banen bestaat uit twee banen, met uitzondering van één mannelijke deelnemer (C8) die er vijf verschillende banen op nahoudt. Verder bestaan zes van de twintig multi-jobs uit twee soortgelijke functies, zoals postbezorger in loondienst bij twee verschillende postbedrijven (C9) of financieel adviseur in loondienst en als zelfstandige (H10). De overige baansamenstellingen bestaan uit heterogene werksoorten, zoals administratief medewerker bij het Ministerie van Justitie én barkeeper bij een horecagelegenheid (C2) of apothekersassistente én zelfstandig dementieconsulente (H3). De meeste cases betreffen een multi-job-transitie waarbij men er een nieuwe baan bij is gaan doen, boven op een hoofdbaan die men al langere tijd heeft. Gemiddeld werkt men 26 uur per week in de eerste (hoofd)baan tegenover gemiddeld 11 uur in de tweede baan.

\section{Diverse multi-jobbing-situaties}

Wat betreft de push- en pullmotieven voor de transitie naar meerdere banen zijn er verschillende hoofdcategorieën van motieven onderscheiden: institutioneel, arbeidsmarkt, financieel, werkinhoudelijk en persoonlijk (incl. gezondheids- of werk-privéfactoren). Samen met het antwoord op de vraag of de huidige multijob-situatie voor de toekomst wel/niet de gewenste baansituatie was, kon de huidige multi-job-situatie door ons onderverdeeld worden in drie hoofdsituaties: multi-jobbing als 'noodsituatie', als 'ideaalsituatie' of als 'overgangssituatie'. We gebruiken de term 'situatie', omdat de tweede baan als tijdelijke situatie of als permanente situatie werd beschouwd. Figuur 1 toont schematisch het onderscheid tussen de verschillende multi-job-situaties op het moment van het onderzoek.

De twee balken geven de wensen op het gebied van het hebben van meerdere banen weer. Het onderscheid tussen het combineren van meerdere banen als 'noodsituatie' en als 'overgangssituatie' wordt bepaald door de wens om uiteindelijk terug te willen naar één baan die gelijk is aan de hoofdbaan of juist de wens van één baan die anders is dan de hoofdbaan. Multi-jobbing als 'ideaalsituatie' toont twee doorlopende balken, wat duidt op de wens om ook voor de toekomst in meerdere banen te willen blijven werken. Dit is een belangrijk onderscheid in de kijk op het hebben van meerdere banen. Er zijn noodzaakgedreven multi-jobbers, kansgedreven multi-jobbers, maar dus ook veranderingsgedreven multi-jobbers met de wens dat men met de tweede baan kan voorsorteren op een andere (loop)baan. Figuur 2 toont vervolgens de genoemde push- en pullmotieven bij elk van de multi-job-situaties. We gaan hier in de volgende paragraaf verder op in. 
Werkende wil één soortgelijke baan...

Werkende wil meerdere banen..

Werkende wil één andere baan..

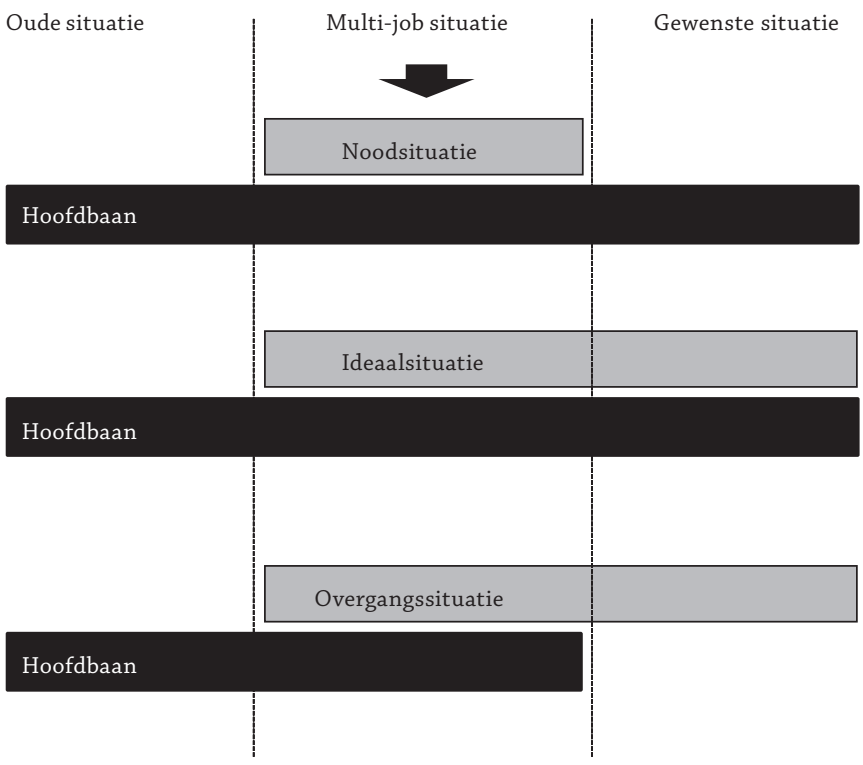

\section{Figuur 1 Weergave van drie verschillende multi-job-situaties}

\section{Multi-jobbing als noodsituatie}

De multi-job als noodsituatie wordt in hoofdzaak getypeerd als een onvrijwillige transitie, waarbij multi-jobbers $(n=4)$ aangeven dat de huidige situatie wat hen betreft tijdelijk is en dat ze voor de toekomst graag weer (fulltime) zouden terugkeren naar de 'oude' situatie van een enkele baan in loondienst (in dezelfde werksoort als voorheen). Zoals wordt gesteld door de fulltime elektronicaverkoper die er voor 8 uur in de week ook een baan als softwareontwikkelaar bij is gaan doen (C4): 'Als het financieel niet meer nodig is, stop ik er mee. Waarschijnlijk als mijn dochters zelfstandig zijn.'

Push/pull-motieven De overeenkomst is dat de multi-jobbers in deze noodsituatie alle vier een combinatiebaan hebben. Een andere overeenkomst is dat in vergelijking met de andere cases bij deze multi-jobbers duidelijke financiële push-factoren een rol spelen - één baan biedt onvoldoende uren/loon om financieel rond te komen. Een extreem voorbeeld in dit onderzoek is het hebben van vijf verschillende kleine banen naast elkaar (C8). Deze respondent is in deze situatie terecht gekomen doordat hij na een faillissement als 45-plusser niet meer als interimmanager/consultant aan de slag komt en de WW-uitkeringstermijn is verstreken: 'Ik heb geen inkomsten meer: dan moet je alles aannemen om te kunnen overleven.'

Voor een jeugdarts bij twee zorginstellingen (C3) speelt echter een institutionele push-factor een rol: één parttime baan als arts biedt onvoldoende bijscholingsuren om de benodigde opleidingspunten te behalen voor de vijfjaarlijkse herregistratie als jeugdarts. 


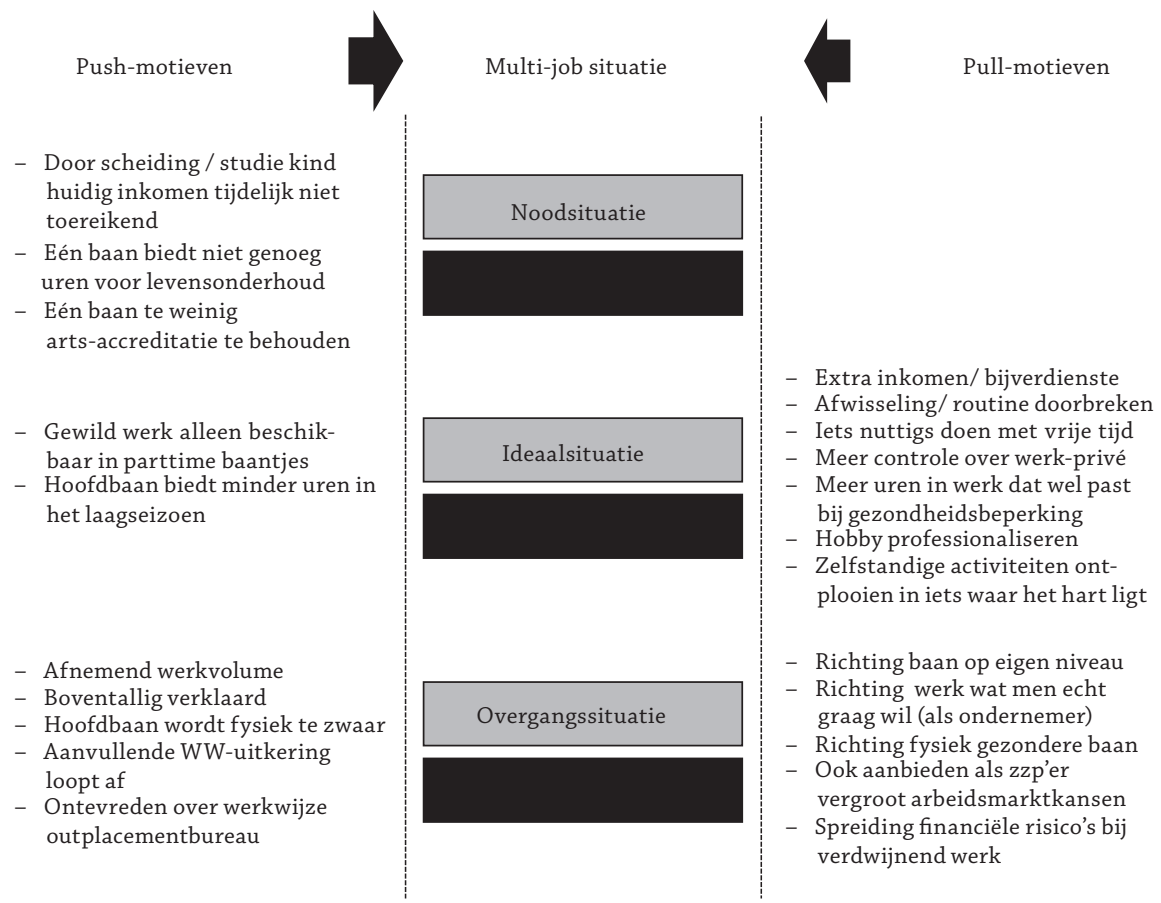

\section{Figuur 2 Genoemde push-en pullmotieven bij drie verschillende multi-job-} situaties

\section{Multi-job als ideaalsituatie}

De helft van de geïnterviewden $(\mathrm{n}=10)$ typeren hun multi-job als een ideaalsituatie. Deze gewenste arbeidsmarktpositie wordt gekenmerkt door multi-jobbers die aangeven dat de huidige situatie van meerdere banen er een is die ze voor de toekomst verkiezen boven het hebben van één baan in loondienst. Zowel combinatiebanen als hybride banen worden getypeerd als ideaalsituatie. Zo stelt een administratief medewerker met daarnaast een baan als barkeeper (C2): 'Mijn pensioen is nog ver weg. Ik leef met de dag, maar voorlopig vind ik het leuk om beide banen te combineren.' In een hybride situatie, stelt een treinmanager die daarnaast als zelfstandige een eigen massagepraktijk is begonnen (H4): 'Dit is ideale combinatie. Te zijner tijd zou ik een dag minder willen werken bij de spoorwegen en de eigen praktijk wat meer uitbreiden.' Dit toont dat de ideaalsituatie nog twee varianten kent: de optimale ideaalsituatie en de suboptimale ideaalsituatie waarbij de verhouding in werktijd in de verschillende banen nog kan of mag veranderen.

Push/pull-motieven Een overeenkomst is dat, in vergelijking met de andere cases, er bij multi-jobbers in een ideaalsituatie een grote verscheidenheid aan voornamelijk pull-motieven een rol spelen. Het hebben van meerdere banen heeft hen meer te bieden of past beter dan één baan in loondienst. We onderscheiden 
hier financiële, werkinhoudelijke, persoonlijke en arbeidsmarkt gerelateerde pullmotieven, zoals respectievelijk 'wil iets extra's verdienen met een tweede baan', 'wil meer afwisseling door verschillende banen', 'wil iets zinnigs doen met vrije tijd', of 'wil weer volwaardig deelnemen aan het arbeidsproces'. In een meerderheid van de cases spelen meerdere pull-motieven tegelijk een rol en kiest men vrijwillig voor een tweede baan.

Een financiële pull-factor is het willen verdienen van iets extra's boven op een reeds acceptabel inkomen. De fulltime hoofdconducteur die samen met zijn vrouw een winkel in duivensportartikelen startte (H9), zag in zijn hobby meer brood: 'Het is een gat in markt en voor mij een pure bijverdienste. De zaken gaan boven verwachting en het wordt alleen maar beter.'

Werkinhoudelijke pull-factoren kunnen liggen in de afwisseling die een tweede baan biedt. De administratief medewerker met een bijbaan als barkeeper (C2) stelt: 'Op deze manier kom ik nog eens in een andere omgeving en onder de mensen. Waarom zou ik mijn leven lang alleen in een kantoor blijven hangen?' Verdere werkinhoudelijke pull-factoren zijn de mogelijkheid om nieuwe vaardigheden op te doen of de mogelijkheid om kennis en vaardigheden die in de hoofdbaan niet (meer) gevraagd worden, toch te kunnen gebruiken. Multi-jobbers in deze laatste categorie zijn er daardoor vaak als zelfstandige iets bij gaan doen. Een coördinator financiële zaken op een school die als zelfstandig gewichtsconsulent mensen is gaan coachen in gezonde eetpatronen (H2) zegt: 'Ik kan in mijn eigen bedrijf iets doen (coaching) wat ik in mijn vaste werk ook graag zou doen, maar waarvoor geen mogelijkheden zijn.'

Een persoonlijke reden om er iets bij te doen is bijvoorbeeld om iets leuks of zinnigs te doen met je vrije tijd. De technisch beheerder in vaste dienst die daarnaast voor gemiddeld twee uur in de week ook technisch werk via het uitzendbureau aanneemt (C10), zegt daarvoor als hoofreden te hebben: 'Ik vind het vooral leuk om technische klusjes te doen. Ik heb 1 dag in de week extra vrij omdat ik 4 × 10 uur werk.' Gevraagd naar hoe hij de combinatie in de toekomst ziet, blijft hij vooral trouw aan zijn hoofdbaan: '[Bedrijf] is mijn hoofdbaan en die gaat voor. Zo lang ik het prettig blijf vinden, blijf ik het combineren. Ik kan me voorstellen dat als ik wat ouder wordt het te zwaar voor me wordt. Dan stop ik er mee.' Voor de postbezorger/sorteerder bij twee verschillende werkgevers (C9) speelt een ander motief mee. Voor hem is zijn multi-job-situatie er ook een die hij niet wil verlaten, mede vanwege zijn berusting bij de arbeidsmarktrealiteit: 'Werk wat ik leuk vind, is vrijwel alleen beschikbaar in kleine baantjes; combineren maakt het mogelijk om dit werk toch voltijds te doen.'

\section{Multi-job als overgangssituatie}

Het derde deel geïnterviewden $(n=6)$ typeren hun multi-job als een overgangssituatie. Zij geven aan dat ze op termijn de 'oude' loondienstsituatie willen of moeten verlaten, en dat ze daarbij bewust kiezen voor een nieuwe, andersoortige functie of een nieuwe arbeidsbetrekking in loondienst of in zzp-verband. Op het moment van bevraging zit men in een multi-job-situatie. Zo vertelt een hbogeschoolde die naast een uitzendbaan als kok er oproepwerk als activiteitenbegeleidster bij een zorginstelling voor ouderen bij is gaan doen (C5): 'Het liefst heb ik weer één werkgever. Ik wil weer graag ergens thuishoren en loyaal kunnen zijn aan mijn 
werkgever. (...) Ik wil vooral ook werk dat aansluit bij mijn opleiding, ervaring en interesse. Het oproepwerk als activiteitenbegeleider bij [naam instelling] is sinds lange tijd weer werk dat op mijn eigen niveau zit.'

Een verzorgende I(ndividuele) G(ezondheidszorg) op uitzendbasis is via een bemiddelingsbureau ook als zzp'er in de thuiszorg gaan werken (H5). Over het liever doorgaan als zzp'er in plaats van uitzendkracht zegt ze het volgende: ' $k$ wil zeker zo doorgaan. Je hebt meer vrijheid om te kiezen wat je wilt doen en wanneer. Het is persoonlijker en beter vol te houden.'

Push/pull-motieven Meer dan bij multi-jobbing als noodsituatie en ideale situatie spelen bij multi-jobbing in een overgangssituatie zowel push- als pull-motieven in gelijke mate een rol. Push-motieven zijn veelal financieel en institutioneel van aard. Diverse multi-jobbers in een overgangssituatie verwachten dat hun inkomen niet gegarandeerd is in de oude loonsituatie en zoeken met hun toegevoegde baan alvast een alternatief. Een duidelijk financieel push-motief wordt geformuleerd door een luitenant-kolonel die door inkrimpingen bij defensie in een outplacementtraject zit (H7): 'Ik ben een eigen onderneming gestart als back-up of contingency-plan om voor inkomen te zorgen, mocht het niet lukken nieuw werk te vinden in een vaste baan.' Een institutioneel push-motief is dat sommige multi-jobbers zich vanwege een aflopende aanvullende WW-uitkering op hun baan zich voor extra uren zijn gaan oriënteren op de arbeidsmarkt. Pull-motieven voor multi-jobbing zijn er in een overgangssituatie ook. Hierbij wordt de aantrekkelijkheid van de multi-job bepaald door het willen starten van een eigen onderneming, terwijl men ondertussen nog even vasthoudt aan de financiële zekerheden van een baan in loondienst.

\section{Multi-jobbing als employability-strategie}

Bij de push- en pull-motieven wordt duidelijk dat reeds in een beperkte groep geïnterviewden grote diversiteit bestaat in de redenen om van één naar meerdere banen te gaan. Naast de motieven benoemen de geïnterviewden ook employability-gerelateerde aspecten als het gaat om het behoud van baan-, werk- en/of inkomenszekerheden. Hoe komt het dat men vanuit de situatie van één baan in combinatie met het transitiemotief niet (meteen) kiest voor het gaan naar één andere beter betaalde of inhoudelijk beter passende baan? Waarom is specifiek multi-jobbing het gekozen alternatief?

Wanneer multi-jobbing uit financiële nood gebeurt, kiezen sommigen er wel bewust voor om er tijdelijk een baan bij te willen doen in plaats van bijvoorbeeld het financiële uitgavepatroon naar beneden bij te stellen of een beter betaalde baan te zoeken. Daarbij zitten redenen als 'het ondanks een recente scheiding willen behouden van de eigen levensstandaard' (C4) of 'samen met de studiekosten van een kind, deze ook de mogelijkheid willen bieden om uitwonend te studeren' (C6). Zij zoeken dan (tijdelijk) een extra inkomensbron, omdat men te maken heeft met extra uitgaven vanwege bijvoorbeeld een scheiding of de studiekosten van een kind. Deze multi-jobbers zien hun tweede baan dan ook als een tijdelijke financiële noodzaak, waarbij de tweede baan in de zekerheid van voldoende inko- 
men voorziet boven op de baanzekerheid in de vaste hoofdbaan. Dit geldt niet voor de hbo-geschoolde man met vijf baantjes (C8) die vooral de betrekkelijke zekerheid van voldoende inkomen zoekt bij gebrek aan perspectief op baan- of werkzekerheid: 'Ik heb nergens opleidingsrechten of -mogelijkheden. Dat maakt het nog moeilijker om weer uit deze situatie te komen. Ik heb zelf geen geld meer om opleiding te volgen. Ook ontbreekt het me aan energie om te solliciteren.'

Wanneer multi-jobbing als de ideaalsituatie wordt beschouwd, zijn de pull-factoren zoals iets extra's verdienen, meer afwisseling of 'iets leuks ernaast doen' wel op de voorwaarde dat men de opgebouwde zekerheden in de hoofdbaan deels kan behouden. Dit geldt vooral voor de acht van de tien multi-jobbers in deze ideaalsituatie die er naast een vast dienstverband iets bij zijn gaan doen. Wanneer de financiële coördinator én zelfstandig gewichtsconsulent (H2) wordt gevraagd naar de mogelijke wens om volledig zelfstandig te gaan, zegt hij: 'Ik wil op dezelfde manier als nu doorgaan. Ik heb het naar mijn zin bij mijn werkgever en doe in mijn eigen bedrijf wat ik leuk vind. Meer als consulent gaan werken? Nee, ik ben nog te kort bezig. Als het goed gaat, wil ik maximaal nog een dag minder gaan werken in het onderwijs. Ik wil niet volledig als zelfstandige werken. Dat heeft te maken met financiële zekerheid.' Ditzelfde argument geldt ook voor de treinsteward/winkelier die, ondanks zijn goedlopende duivensportwinkel, zijn baan op de trein niet volledig wil gaan opgeven: 'Ik wil mijn vaste baan niet opgeven, daar is de markt te grillig voor. Alleen een eigen winkel is te onzeker, het is een gevoelige business. Over vijf jaar wil ik wel minder gaan werken bij [werkgever hoofdbaan], omdat mijn pensioen dan veilig is gesteld. Ik zou bijvoorbeeld wel twee dagen willen inleveren.'

Voor de manager van een winkel in streekproducten die ook zelfstandig psychosociaal hulpverlener met behulp van honden is (H8), spelen de seizoensfluctuaties in haar inkomen een rol. Voor haar bieden de twee banen inkomenszekerheid gedurende het hele jaar: 'De combinatie winkelwerk met hondentrainingen is ook nodig om in de winter een volledig inkomen te kunnen verwerven. De winkel is dan twee dagen per week minder open waardoor ik minder uren kan maken. Ik hoop dat ik in de winter twee trainingen per week met de hond kan geven.'

Multi-jobbers die twee banen als een overgangssituatie zien, vermelden ook redenen om nog even vast te houden aan de hoofdbaan. De 60-jarige apothekersassistent bij een ziekenhuis die zich daarnaast als zelfstandig dementieconsulent op de markt oriënteert (H3), zegt hierover: 'Ik zou graag tot mijn 65e combineren en daarna door als zelfstandig dementieconsulente. Daarbij is apothekersassistent ook een leuke baan en levert baanzekerheid en pensioenopbouw.' Voor de verzorgende IG (H5) speelt mee dat, ondanks de wens om uiteindelijk zelfstandig door te gaan, een hybride constructie haar wegens haar gezondheidsklachten verzekert tegen arbeidsongeschiktheid. In de overgang naar volledig zzp-schap is dat voor haar een belangrijk punt: 'Ik wil me komende jaren wel voor ziekte gaan verzekeren, vooral voor langdurige uitval, zodat ik geen uitzendwerk ernaast hoef te doen.' Voor de multijobbers in de overgangssituatie die ook push-factoren ondervinden in de vorm van een aflopend dienstverband of ontevredenheid met een hoofdbaan onder opleidingsniveau, biedt de tweede baan een andere oriëntatie op werk dat men 
uiteindelijk wil gaan doen. In het licht van het behoud van werkzekerheid is het een bewuste employability-strategie. Zoals het wordt verwoord door de luitenantkolonel die zich vanuit een outplacementsituatie als zelfstandig adviseur (H7) actief oriënteert op een nieuwe loopbaan: 'Ik heb echt de indruk dat je er een extra optie bij biedt: je kunt je zelf dus aanbieden voor een vast contract of een tijdelijk contract. Maar nu kan ik mezelf ook voor een omlijnde opdracht aanbieden of voor een bepaalde tijd laten inhuren. Had dit van tevoren niet bedacht. Het eigen bedrijf geeft me een andere status dan werkzoekende, wat het makkelijker voor me maakt me te presenteren.' De instellingskok die met het aannemen van een extra baan als activiteitenbegeleider (C5) weer sinds lange tijd werk op haar eigen niveau doet, zegt: 'Ik merk dat het mij weer perspectief geeft. Daarom zie ik het als een kans.' Voor haar voelt de tweede baan als een opstap naar haar oude (en hogere) werkniveau.

\section{Discussie}

Het doel van deze studie was meer inzicht te verkrijgen in multi-jobbing als arbeidsmarktverschijnsel. Hiertoe hebben we een kwalitatieve studie verricht onder twintig multi-jobbers van 45 jaar en ouder die recentelijk vanuit een situatie van één baan in loondienst een transitie hebben gemaakt naar een arbeidssituatie bestaande uit meerdere banen. We onderzochten de verschillende motieven voor multi-jobbing.

\section{Multi-job-motieven}

De interviews laten ten aanzien van de multi-job-motieven zien dat ze duiden op drie verschillende situaties: multi-jobbing als 'noodsituatie', als 'ideaalsituatie' en als 'overgangssituatie'.

Multi-jobbing in een noodsituatie wordt vooral gedreven door financiële pushmotieven. Het niet kunnen maken van genoeg werkuren om in de levensstandaard te kunnen voorzien is de primaire reden voor vier van de twintig geïnterviewden om naast hun baan in loondienst er een baan bij te doen. Dit sluit aan bij de klassieke hours-constraint-hypothese. Maar er spelen ook andere motieven een rol om gedwongen een extra baan te nemen, zoals het moeten halen van voldoende punten voor behoud van de accreditatie van jeugdarts.

Multi-jobbing als ideaalsituatie is interessant, omdat deze in de wetenschappelijke literatuur weinig belicht wordt. Dat werknemers kiezen voor een atypische arbeidssituatie, wordt vooral theoretisch ingestoken vanuit de wens van werknemers voor extra inkomen of voor meer afwisseling in het werk (heterogeneous jobs hypothese). In dit onderzoek zien we ook andere redenen, zoals de wens om iets nuttigs te doen met je vrije tijd, of om bijvoorbeeld je hobby verder te kunnen professionaliseren. Voor hybride multi-jobbers wordt de aantrekkelijkheid van de combinatie van banen mede ingegeven door een zekere vorm van risicospreiding waarbij ze, ondanks hun inspanningen en wensen om inkomen uit zelfstandige activiteiten te vergaren, de financieel zekere inleg vanuit een vaste baan in loondienst niet willen opgeven. Dit sluit aan bij onderzoek van Bruins (2009), waaruit 
bleek dat de financiële zekerheid die de baan in loondienst biedt voor hybride ondernemers de belangrijkste reden is om niet fulltime te gaan ondernemen.

Als laatste onderscheidden we multi-jobbing als overgangssituatie tussen een baan die verdwijnt of niet meer past en een nieuwe, andere baan waarin men kan blijven werken. Hier past wat Wu et al. (2009) en Bell et al. (1997) omschrijven als de hedging-hypothese van multi-jobbing. Wetende dat de oude baansituatie verdwijnt, onzeker of niet gewenst is, sorteert men voor in een nieuwe baan, terwijl men ondertussen nog even vasthoudt aan de oude baan. Eerdere literatuur spreekt al van de opstap-functie die multi-jobbing kan hebben (Urlings, 2009; Panos et al., 2014; Guariglia \& Kim, 2006), wanneer het tijdelijk stapelen van twee banen de geleidelijke opstap biedt voor een nieuwe baan in loondienst of voor de opstap naar volledig zzp-schap. In dit onderzoek vermelden multi-jobbers in een overgangssituatie in gelijke mate push- en pull-motieven. Daarin verschilt het van de noodsituatie (voornamelijk push-factoren) en de ideaalsituatie (voornamelijk pull-factoren). Dat deze tussenvorm van bepalende factoren van arbeidsmarktgedrag niet vreemd is, werd ook al getoond door Caliendo en Kritikos (2009) in hun paper met de veelzeggende titel: 'I want to, but I also need to'. Daarin onderzochten ze de motieven van nieuwe Duitse ondernemers/zzp'ers, waarbij bleek dat de grote meerderheid zowel push- (bijv. ontslag in vorige baan) als pull-motieven (bijv. eigen baas willen zijn) rapporteerden.

Wat deze kwalitatieve studie toont, is dat het maken van een transitie naar een multi-job wordt ingegeven door zeer verschillende motieven. Het klassieke hours constraints-denken (multi-jobbing als reactie op de financiële misfit tussen het gewenste inkomen en het aantal werkuren) volstaat niet als enige verklaring voor multi-jobbing als (atypisch) arbeidsmarktgedrag. De positieve insteek van multijobbing als oplossing voor een psychologische misfit tussen wat men in het werk en leven wenst (bijv. uitdaging, voldoening, extra inkomen voor leuke dingen) en wat de hoofdbaan te bieden heeft, is evenzeer een motief om in een tweede baan deze wensen toch te vervullen. Daarnaast lijkt multi-jobbing een oplossing te kunnen bieden voor arbeidsmarktmisfits tussen vraag en aanbod waarbij de baanzekerheid afloopt in de ene baan en men alvast nieuwe (inkomens)zekerheden zoekt in een nieuwe baan.

\section{Multi-jobbing en de employability-kansen op latere leeftijd}

In het licht van de geringe vrijwillige arbeidsmobiliteit van 45 -plussers is multijobbing te typeren als arbeidsmarktgedrag dat de employability van werknemers in een latere loopbaanfase veelal ten goede komt. De geïnterviewden maken gebruik van hun verworven zekerheden, om in een tweede baan (soms tijdelijk) hun inkomen aan te vullen, meer uitdaging en afwisseling te zoeken, hun competenties beter te benutten of alvast voor te sorteren op een nieuwe baan. Op de vraag waarom men niet één beter betalende baan of volledig ondernemerschap nastreeft of meteen van baan naar baan gaat, geeft de behoefte aan zekerheid een goed beeld van de algemene employability-impasse in een latere loopbaanfase. Met een veranderende arbeidsmarkt waarbij zowel flexibilisering als zelfstandig ondernemerschap belangrijke pijlers zijn, kan (hybride) multi-jobbing het beleids- 
debat over deze ontwikkelingen voeden met werkbare inzichten. Het raakt aan de grenzen van oudere werknemers die niet willen flexibiliseren, omdat ze daar te veel voor hebben opgebouwd, en de zzp'ers die niet volledig willen ondernemen, omdat het ondernemerschap voor velen daar te risicovol voor is.

Multi-jobbing is arbeidsmarktgedrag dat de ruimte typeert tussen volledige stilstand op de arbeidsmarkt en volledige dynamiek. Wat betreft van-werk-naarwerk-programma's raden we dan ook aan meer na te denken over 'gedeeltelijke' of 'geleidelijke' arbeidsmobiliteit. Hierbij gaan werknemers gedeeltelijk naar een andere baan terwijl men parttime aan de oude werkgever blijft verbonden, of gaan werknemers geleidelijk naar een andere baan die ze er eerst voor een deel bij gaan doen. Het betreffen tussenvormen die recht doen aan de (afbreuk)risico's die vooral ook oudere werknemers lopen wanneer ze zich na lange tijd weer willen of moeten oriënteren op nieuwe loopbaanstappen.

Met deze studie onder werknemers van 45 jaar en ouder maken vooral de hybride cases duidelijk, dat multi-jobbing een persoonlijke inzetbaarheidsstrategie kan inhouden. De voorbeelden waarbij bewust wordt gekozen voor zzp-schap naast de hoofdbaan, om gezondheidsproblemen zelf te kunnen reguleren, om een hobby te professionaliseren of om zich anders te kunnen aanbieden op de arbeidsmarkt, tonen dit. Ook de leidinggevende speelde in een van de cases een prominente rol. Door een seniorenregeling hoefde een van de geïnterviewden (H2; 56 jaar) een dag per week minder te werken. Ondertussen miste hij de mogelijkheden in zijn werk om mensen te coachen. Zijn leidinggevende stelde toen voor om op zijn vrije seniorendag iets nieuws op te pakken. Als zelfstandig gewichtsconsulent heeft hij op die dag de coachingsbehoefte kunnen invullen. In HRM-beleid kan dus ook buiten de organisatie de ontwikkeling van oudere werknemers gestimuleerd worden. Dat dit voor oudere werknemers een kansrijke route kan zijn, blijkt ook uit de statistiek dat 45-plussers het grootste aandeel hybride multi-jobbers kent (zie Dorenbosch et al., 2013). Het combineren van een baan met zelfstandig ondernemerschap is op een later moment in een loopbaan dus niet vreemd.

\section{Aanbevelingen voor beleid}

Deze studie toont op kwalitatieve wijze de verschillende kanten van het fenomeen multi-jobbing. Hoewel het aantal multi-jobbers op de arbeidsmarkt niet gering is, is het een onderbelichte vorm van arbeidsmarktgedrag. Vanwege het grote aantal parttimers op de Nederlandse arbeidsmarkt is het verschijnsel des te interessanter, omdat multi-jobbing voornamelijk constructies met meerdere parttime banen omvat. Het is dan ook de vraag hoeveel parttimers daadwerkelijk één parttime baan hebben, en welk deel meerdere parttime betrekkingen combineert. Huidige parttime cijfers kunnen een vertekend beeld geven. Daaraan gerelateerd is het vraagstuk van een steeds groter aanbod van parttime banen op de arbeidsmarkt. Door scherpe concurrentie kunnen sommige werkgevers soms geen voltijdscontracten meer bieden en zal er mogelijk een groeiend aanbod aan kleine baantjes komen. De vraag is dan ook in welke mate multi-jobbing in de toekomst zal toenemen als gevolg van veranderingen in het urenaanbod in banen op de arbeidsmarkt. Zal er een toename zijn van multi-jobbers uit nood? 
Anderzijds biedt de parttime infrastructuur van de Nederlandse arbeidsmarkt ook unieke kansen. Anders dan in andere landen is het deeltijdwerken in Nederland meer gecultiveerd. Het is in organisaties makkelijk bespreekbaar, wat ook zou kunnen gelden voor het hebben van een tweede baan in een latere loopbaanfase. Om dit te stimuleren kunnen toekomstige cao-afspraken over seniorenregelingen zich richten op het instellen van een 'ondernemersdag' in plaats van een vrije, maar doorbetaalde 'ontziedag'. Ondernemersdagen worden benut voor het onderzoeken van de mogelijkheden tot het vergaren van (deel)inkomen uit activiteiten als zelfstandige of bij een andere werkgever. Op deze dag is men ook vrijgesteld van regulier werk, maar kunnen de loonkosten worden geïnvesteerd in een zelfstandige loopbaandoorstart, met een zogenoemde 'doorstart-up' als resultaat, waarin men langer kan blijven participeren ook voorbij de wettelijke pensioenleeftijd.

\section{Literatuur}

Bell, D.N.F., Hart, R.A. \& Wright, R.E. (1997). Multiple job holding as a hedge against unemployment. CEPR discussion paper series No. 1626.

Bosch, N. \& Weel, B. ter (2013). Labour-market outcomes of older workers in the Netherlands: Measuring job prospects using the occupational age structure. Den Haag: CPB discussion paper no. 234.

Bruins, A. (2009). Van baan naar eigen baas. Zoetermeer: EIM.

Caliendo, M. \& Kritikos, A.S. (2009). 'I Want to, But I Also Need to': Start-Ups Resulting from Opportunity and Necessity. Bonn: IZA Discussion paper 4661.

CBS (2014). Aantal werknemers met twee banen neemt toe. CBS Webmagazine,

vrijdag 14 november 2014. URL: http://www.cbs.nl/nl-NL/menu/themas/arbeidsocialezekerheid/publicaties/artikelen/archief/2014/2014-4142-wm.htm

Deelen, A., Euwals, R. \& Muffels, R. (2014). Nederlandse arbeidsmarkt in Europees perspectief: jongeren mobiel, ouderen honkvast. Me Judice, 2 maart.

Dickey, H., Watson,V. \& Zangelidis, A. (2011). Is it all about money? An examination of the motives behind moonlighting. Applied Economics, 43, 3767-3774.

Dorenbosch, L., Boneschansker, O., Sanders, J. \& Koppes, L. (2013). Redenen voor het combineren van meerdere banen. Economisch Statistische Berichten (ESB), 98(4666), 480-482.

Dorenbosch, L., Sanders, J. \& Beudeker, D. (2015). Multi-jobbing: wenselijk of onwenselijke arbeidsmarktdynamiek? In K. Chkalova, A. Goudswaard, J. Sanders \& W. Smits (red.), Dynamiek op de Nederlandse arbeidsmarkt (pp. 170-196). Den Haag: CBS/TNO.

Guariglia, A. \& Kim, B.Y. (2006). The dynamics of moonlighting in Russia: What is happening in the Russian informal economy. Economics of Transition, 14(1), 1-45.

Hipple, S.F. (2010). Multiple jobholding during the 2000s. Monthly Labor Review, July, 21-31.

Huiskamp R., Sanders, J. \& Bossche, S. van den (2011). Meerdere banen: noodzaak of uitdaging? Tijdschrift voor Arbeidsvraagstukken, 27(2), 156-175.

Kösters, L., Smits, W. \& Vries, R. de (2013). De ene zzp'er is de andere niet. In R. van Gaalen, A. Goudswaard, J. Sanders \& W. Smits (red.), Dynamiek op de Nederlandse arbeidsmarkt (pp. 139-152). Den Haag: CBS/TNO.

Neefs, B. \& Herremans, W. (2011). Werken bij maanlicht! M/V met meerdere jobs op de Vlaamse arbeidsmarkt. Over.werk Tijdschrift van het Steunpunt WSE, 3, 106-115. 
OECD (2014). Ageing and employment policies: Netherlands 2014: Working better with age. OECD Publishing.

Panos, G.A., Pouliakas, K. \& Zangelidis, A. (2014). Multiple job holding, skill diversification, and mobility. Industrial Relations, 53(2), 223-272.

Raffiee, J. \& Feng, J. (2014). Should I quit my day job? A hybrid path to entrepreneurship. Academy of Management Journal, 570, 936-963.

Renna, F. \& Oaxaca, R.L. (2006). The economics of dual job holding: A job portfolio model of labor supply. Bonn: IZA Discussion Paper No. 1915.

Reynolds, P.D., Camp, S.M., Bygrave, W.D., Autio, E. \& Hay, M. (2001). Global Entrepreneurship Monitor. London: London Business School and Babson College.

SCP (2015). Aanbod van Arbeid 2014: Arbeidsdeelname, flexibilisering en duurzame inzetbaarheid. Den Haag: Sociaal Cultureel Planbureau.

Shishko, R. \& Rostker, B. (1976). The economics of multiple job holding. The American Economic Review, 66, 298-308.

Urlings, N. (2009). Van werknemer naar ondernemer. Den Haag: CBS.

Wilthagen, T. \& Tros, F. (2004). The concept of flexicurity: a new approach to regulating employment and labour markets. Transfer, 10(2), 166-186.

Wu, Z., Baimbridge, M. \& Zhu, Y. (2009). Multiple job holding in the United Kingdom: evidence from the British Household Panel Survey. Applied Economics, 41, 1-16.

Ybema J.F., Geuskens, G.A., Heuvel, S.G. van den, Wind A. de, Leijten, F.R.M., Joling, C., Blatter, B.M., Burdorf, A., Beek, A.J. van der \& Bongers, P.M. (2014). Study on Transitions in Employment, Ability and Motivation (STREAM): The design of a four-year longitudinal cohort study among 15,118 persons aged 45 to 64 years. British Journal of Medicine and Medical Research, 4(6), 1383-1399. 